A Smart Energy Policy 
This page intentionally left blank 


\section{A Smart Energy Policy}

\section{An Economist's Rx for Balancing}

Cheap, Clean, and Secure Energy

James M. Griffin

Yale University Press

New Haven \& London 
Published with assistance from the Louis Stern Memorial Fund.

Copyright $\left({ }_{0} 2009\right.$ by James M. Griffin.

All rights reserved. This book may not be reproduced, in whole or in part, including illustrations, in any form (beyond that copying permitted by Sections 107 and 108 of the U.S. Copyright Law and except by reviewers for the public press), without written permission from the publishers.

Set in Adobe Garamond type by The Composing Room of Michigan, Inc. Printed in the United States of America by Sheridan Books, Ann Arbor, Michigan.

Library of Congress Cataloging-in-Publication Data

Griffin, James M., I944-

A smart energy policy : an economist's Rx for balancing cheap, clean, and secure energy / James M. Griffin.

p. $\mathrm{cm}$.

Includes bibliographical references and index.

ISBN 978-0-300-I4985-2 (cloth : alk. paper) I. Energy policy-United States.

2. Climatic changes-United States. I. Title.

HD9502.U52 G75 2009

$333.790973-\mathrm{dc} 22$

2008052784

A catalogue record for this book is available from the British Library.

This paper meets the requirements of ANSI/NISO Z39.48-1992 (Permanence of Paper). It contains 30 percent postconsumer waste (PCW) and is certified by the Forest Stewardship Council (FSC).

IO 99876654322 I 